1 Universidade de São Paulo (USP) - São Paulo (SP), Brasil.

beth.araujolima@gmail.com

2 Universidade Estadual Paulista (Unesp) - Assis (SP), Brasil.

\section{Aesthetic and body practices: creation and production of subjectivity in psychosocial}

\section{care}

\author{
Práticas estéticas e corporais: criação e produção de subjetividade na \\ atenção psicossocial
}

Elizabeth Araújo Lima1,2, Guilherme Providello2,3, Juliana Araújo Silva,2, Juliana Maria Padovan

Aleixo ${ }^{2}$, Lívia Pellegrini2, Paula Carpinetti Aversa2 ${ }^{2}$, Tais Barrenha², Tânya Marques Cardoso²

DOI: $10.1590 / 0103-11042021129131$

\begin{abstract}
Aesthetic and body practices have played a significant role in psychosocial care, in the context of the Brazilian Psychiatric Reform. Proposals that invent other ways of producing health and subjectivity, associated with social participation, have valued the diversity of expression in mental health and the difference in forms of existence. In order to study these practices and create a field of communication and collective production of their singularities and their common plan, a group of researchers met in the Graduate Program in Psychology at Universidade Estadual Paulista, creating the line of research 'Aesthetic and body practices in the psychosocial care: processes of creation and production of subjectivity'. In the inquiries developed, the relations between art and mental health, the production of public policies related to the field, the development of clinical, artistic and cultural practices and the formulation of concepts and theoretical perspectives that support these practices were explored. In this paper, the health and culture public policies that have been developed in Brazil in the last 30 years, their intersectoral articulation and some practical experiences in this field, which we have developed and researched, will be briefly presented.
\end{abstract}

KEYWORDS Mental health. Public policy. Art. Culture.

RESUMO Práticas estéticas e corporais têm ocupado um lugar significativo na atenção psicossocial, no contexto da Reforma Psiquiátrica brasileira. Propostas que inventam outras formas de produção de saúde e de subjetividade, associadas à participação social, têm valorizado a diversidade de formas de expressão em saúde mental e a diferença nas formas de existência. Com o intuito de estudar essas práticas e criar um campo de comunicação e produção coletiva de suas singularidades e seu plano comum, um grupo de pesquisadores se reuniu no Programa de Pós-graduação em Psicologia da Universidade Estadual Paulista e desenvolveu pesquisas articuladas ao projeto 'Práticas estéticas e corporais na atenção psicossocial: processos de criação e produção de subjetividade’. Nessas pesquisas, foram exploradas as relações entre arte e saúde mental, a produção das políticas públicas relacionadas a campo, o desenvolvimento das práticas clínicas, artísticas e culturais e a formulação de conceitos e perspectivas teóricas que sustentem essas práticas. Neste texto, serão apresentadas, brevemente, as políticas públicas de saúde e cultura que foram desenvolvidas no Brasil nos últimos 30 anos, sua articulação intersetorial e algumas experiências práticas nesse campo, que temos desenvolvido e pesquisado.

PALAVRAS-CHAVE Saúde mental. Política pública. Arte. Cultura.

${ }^{3}$ Centro Universitário de Ourinhos (Unifio) - São Paulo (SP), Brasil. 
The risk - I am taking the risk of discovering

a new land.

(Clarice Lispector, in Água Viva)

\section{Introduction}

Psychosocial care was configured as a set of practices and knowledge serving as a guide to the creation of health care devices in the context of the Brazilian Psychiatric Reform (RPb). Among these devices, aesthetic and bodily practices gained relevance, expanding the possibilities of care in artistic and cultural projects. This perspective started being developed in the 1980s, when social movements and public mobilization for democracy led to important changes in the country's political scenario. The struggle for the end of the military dictatorship, the construction of the political opening and the strengthening of various advocacy movements for the rights of all created the conditions for the promulgation of a new Constitution, in 1988, which was followed by the construction of public policies based on the ideas of health and culture as fundamental rights.

These policies were strengthened over the last 30 years and are today strongly threatened by an agenda of setbacks. Thus, it is evident that the construction of policies does not indicate the end of the struggles. It is always at the junction of struggles that forms of producing and exercising rights are established and these can only be guaranteed in the public space, when one belongs to a community within which it is possible to act and participate, according to Arendt ${ }^{1}$. It was with the purpose of building this public space that workers of health, culture and arts as well as users of public services and their families joined the social movements and opened a path of intersectoral action, redefining the presence of artistic and cultural activities from an ethicalaesthetic-political perspective.

In this context, aesthetic and body practices started to instigate the invention of other forms of production of health and subjectivity, associated with social participation and cultural production. Thus, new articulations between singular experiences and collective life are promoted, in the affirmation of the rights of enjoyment and cultural production and in the valuation of the multiplicity of forms of existence and the diversity of forms of expression.

In order to create a field of communication and collective investigation of these practices, their singularities and their common plan, the project 'Aesthetic and body practices in psychosocial care: processes of creation and production of subjectivity' was created, according to the 'Psychosocial care and public policies' research line of the Graduate Program in Psychology of the Paulista State University (Unesp). The project articulates a network of research that investigates the relationship between art and mental health, production of public policies related to the field, development of clinical, artistic and cultural practices and formulation of the theoretical concepts and perspectives to support these practices ${ }^{2-9}$.

Cartography is the methodological ethos that provides a context to these researches, which follows processes and is marked by a critical attitude encompassing several disciplines. This attitude allows the interlacing of disciplines in the construction of a plan composed of heterogeneous materials and procedures - "components that are theoretical and technological, but also aesthetical, ethical, economic, political and affective"10(74) - in the affirmation of the constructive and inventive character of knowledge production. Research involving human beings was carried out in accordance with ethical principles and was approved by the Research Ethics Committee at Unesp.

In this text, there will be a brief presentation of the public health and culture policies that have been developed in Brazil over the last 30 years, their intersectoral articulation and a few experiences in this field that we came to develop and/or researched. 


\section{The construction of health and culture public policies}

\section{Psychiatric Reform and Psychosocial Care}

Social struggles aimed at the defense and promotion of health as a right mobilized different players and civil society groups around a common project and, through the Health Reform Movement, enabled the creation of the Unified Health System (SUS), founded on the principles of social justice, equality, integrality and universality. The proposal of the SUS thus expresses a radicalization of the democratic project, which goes far beyond the offer of health services and the guarantee of access and consumption of these services, focusing on the creation of health practices committed to the public dimension of life ${ }^{11}$.

In the context of the creation of the SUS and influenced by the experiences of transforming mental health care models carried out in several countries, the Anti-Asylum Struggle emerged. This political and social movement, formed by mental health workers, family members and people with mental suffering has been fighting for the end of asylums and of the practices of violence, torture and ill-treatment taken place in the asylum environment, having as one of its principles the idea that the experience of insanity should be approached in a place of culture.

One of the results of the Anti-Asylum Struggle was the development of the $\mathrm{RPb}$ as a public policy for mental health, based on the structuring of a non-hospital-centric care network. The $\mathrm{RPb}$ was deeply influenced by Italian Democratic Psychiatry, which considered that the patient's cure and adaptation to a productive life were not the challenges to be faced by mental health professionals, but rather the production of life, meaning and sociability. The result of the articulation between the materiality of the institutional space and the potential of subjective resources, named by Franco Rotelli12 as therapeutic economy, should be the emergence of a community marked by solidarity and affection. The materiality of the institutional space comprises the way in which the service is organized, the type of care model that characterizes it, the work regime and the remuneration of the health professional. In this context, the shift from the notion of cure to that of the production of life enhances subjective changes while promoting the dismantling of the asylum logic. In this process of paradigm shift, all players are called upon to build a sense of belonging and to weave community ties.

The transmutation of this proposal into a public policy implied the creation of a series of guidelines and ordinances that directed the paradigm shift, in addition to allocating resources for its implementation, enabling access to culture, leisure and health in an interdisciplinary and intersectoral way. Law No. 10,216, of 2001, advocates the right to mental health in new care models and is operationalized by Ordinances No. 336 and No. 189, of 2002, which establish the Psychosocial Care Centers (Caps) and enable the opening of Centers for Coexistence and Cooperatives (Cecco) or Centers for Coexistence and Culture (Cecc). In these environments are held therapeutic, artistic and cultural workshops registered in the SUS Outpatient Information System (SIA/SUS) table, through Ordinance No. 728, of 2002. Their concept is reinforced by the National Conferences on Mental Health and the IV Conference, in 2010, recognized the role they play in the construction of the intersectoral network.

Their implementation and transformation into care actions require overcoming the psychiatric paradigm and imply, according to Amarante, an action in four dimensions: the theoretical-conceptual dimension, which problematizes theories and concepts that support traditional psychiatric knowledge; the technical-assistance dimension, related to the ways of caring; the legal-political dimension, aimed at discussing and redefining 
legislation involving mental patients; and the sociocultural dimension, which encompasses the set of actions aimed at transforming society's relationship with insanity. The sociocultural dimension - which seeks to provoke and destabilize the social ideas related to insanity and involve society in the discussion of the Psychiatric Reform, based on the cultural and artistic production of the social players involved - is one of the "most creative and recognized dimensions, nationally and internationally, of the Brazilian process of psychiatric reform"13(73).

The articulation of these four dimensions underpins a new way of acting in mental health: psychosocial care, which proposes the shift from the psychiatric paradigm to the psychosocial paradigm, comprising the treatment of the subject within an expanded and transdisciplinary clinical practice. The nuclear element of psychosocial care is deinstitutionalization, understood as a process of rupture with the asylum model and a proposal for a new relationship with the experiences of psychological suffering, offering treatment in the territory, producing rapprochement between users and the community, rethinking the conditions of citizenship and developing collective actions to strengthen democratic processes built along with users ${ }^{\mathbf{1 4}}$.

The institutional apparatus of the $\mathrm{RPb}$ is made, above all, of "devices for the production of subjectivity and subjectivation"15(55) that make mental health practices coincide with practices for the production of subjectivities and culture, requiring

an interdisciplinary, transdisciplinary and intersectoral approach, with the resulting construction of a diversity of territorialized care and attention devices 16 (29).

The deconstruction of the mental hospital and asylum model was hence accompanied by the creation of a wide network of devices for care and production of subjectivity focusing their assistance on the sociocultural territory: devices such as workshops and the cooperatives present in the Caps and in the Ceccos, as already mentioned. Several cultural and artistic experiences, guided by the psychosocial paradigm, began to be managed and implemented, expanding the range of mental health care with proposals to ensure opportunities for access, exercise and expression of creative, artistic, cultural and intellectual potentials.

Mental health came to be seen in its relationship with life, coexistence and cultural experiences. Understanding life as movement, ensuring the freedom and support of this movement would be to create favorable conditions for the invention of multiple health possibilities ${ }^{17}$.

\section{Culture as a right and cultural diversity}

In the same period in which progress was made towards expanded care in mental health, a significant change in cultural policies triggered a process of democratization of culture, valuing of cultural diversity and the encouragement by the State of initiatives emerging in different regions in the Country. Issues of subjectivity, territory, ease of access and difference started to become part of the cultural policy agendas that understand culture as a right and an important element for development and reduction of poverty and inequality.

Lima and Ortellado argue that the cultural policies of the period shifted their focus from democratizing access to cultural products to supporting, fostering and providing access to cultural production activities and to the creative process involved, towards an effective cultural democracy. According to the authors, cultural activity generates products or services, but its true wealth lies in the process that takes place over an extended period and involves constant efforts in creation, research and training ${ }^{18}$.

An expanded concept of culture guides these new policies, in which cultural 
manifestations gain in terms of diversity, languages and social functions. Culture is now seen as a common experience, linked to the production of meanings and values and to the expression of the multiplicity of life forms present in a given society ${ }^{\mathbf{1 9}}$. Accordingly, cultural policies are aimed at segments considered to be most vulnerable and begin to include in their agenda popular culture, indigenous culture, (African slave heritage) community culture, and gipsy culture. They shift their focus to the artistic expression of people in psychological distress and/or with disabilities, valuing their artistic-cultural expressions in terms of their diversity and uniqueness. Culture and health begin to overlap.

\section{Health and culture: intersectoral dimensions}

As of 2003, a series of intersectoral initiatives began to be developed between the Ministry of Culture and the Ministry of Health. An example of these initiatives was the holding of the Workshop 'Crazy for Diversity - from the diversity of insanity to the identity of culture', which, in 2007, brought together artists, cultural producers, health professionals, researchers and users of mental health services committed to the development of artistic-cultural projects in the field of mental health ${ }^{20}$. This was followed by the 'Crazy for Diversity' Award, which, in 2009, awarded artistic projects developed by people in psychological distress, by autonomous groups linked to the experience in mental health or by teams of health or cultural institutions or venues.

The confluence points of the set of experiences presented for this award, coming from the cultural and/or health sectors, were: the affirmation of health and culture as a right; the idea that cultural practices can produce health, and that practices in the field of health can produce art and culture; and the belief that artistic and cultural experiments with subjects who have or had experiences of suffering and medicalization can change patterns of discrimination and stigmatization, expand territories for circulation and exchange of experiences, produce new meanings for suffering, create new languages and cultural expressions and produce a richer life for all21.

According to Yasui ${ }^{22}$, the production of the intersectoral dimension implies

building a process involving intense dialogue, which implies recognizing and respecting the specificities and diversities of each field; making visible the conflicts and interests involved, so that actions can be negotiated and agreed upon; uniting powers, holding meetings around themes that permeate all these fields, namely: the improvement of the quality of life, social inclusion and the construction of citizenship for the population 22(155)

This desire to be intersectoral reallocates the role of public policies as an agent to potentiate the creative force existing in everyone, especially in areas where there is greater vulnerability and social risk, taking as a basis the axes of creation, expression, ease of access, dissemination, participation and production of subjectivity. It is mainly about reinvigorating the public dimension of policies, recognizing the leading role of policy creation in the context of collectives and plural public spaces ${ }^{23}$. Public, here, is not understood as belonging to government or state, but refers to the space in which one is among human beings as political beings, that is, the space in which people can exercise their power to act.

\section{Experimentation in the living territory of cities}

Mental health practices in the psychosocial paradigm seek to deconstruct asylums, replacing them with new institutions that expand and move in relation to other sectors. These actions call for the exploration of a world 
beyond walls that yearns for territorial work and a peripatetic clinic ${ }^{24}$.

The psychosocial paradigm proposes the enhancement of resources offered by the territory itself so as to provide care with freedom, encouraging exchanges, interpersonal relationships, sociocultural participation, in a network where destabilization is sustainable so that life can follow its course and its wanderings. This network is composed of several devices, programs and services in health and culture, civil society initiatives and autonomous groups. Together, these initiatives seek to create the conditions for effective monitoring in the living territory of the city, which involves material and immaterial elements of the place: streets, houses, interpersonal relationships, affections, memories, stories and cultural universe, in a game of territorialization, deterritorialization and reterritorialization ${ }^{25}$.

Within the scope of actions that articulate art, health and culture, the so-called 'workshops' gained prominence, introducing various fields of activity into mental health services: crafts, artistic, sports, productive and educational. activities The purpose of these devices is to establish group spaces for socialization, expression and participation, working as an environment of coexistence and care, in order to break with the iatrogenic actions of the asylum model and destabilize the frameworks of the traditional clinic 5 .

Below, we will present some experiments that took place in an intersectoral environment and that were studied in the surveys we carried out. In them, the production of health and subjectivity implied the development of "creation processes aimed at building new languages, new territories, new meanings"25(599).

\section{A Visual Arts Workshop: inventing relations}

Experiments in visual arts within the scope of the Psychiatric Reform take place in many Caps, Ceccos and cultural institutions, open to those interested in different artistic modalities, constituting common spaces in which heterogeneity predominates.

A visual arts workshop held in 2016, on the outskirts of a city in the interior of Minas Gerais, illustrates the power of these devices, which are constituted as laboratories, in which ways of being in the world can be explored and gain expression through the offering of materials, techniques and artistic repertoires. This workshop was developed in weekly meetings in a Unified Sports and Culture Center, had the help of the Social Assistance Reference Center (Cras) in the region and became, for its participants, a territory of existence. The experiments that took place there held a direct dialogue with contemporary art, as the latter has deliberately explored and blurred the boundaries between life and art, allowing life to become aesthetic and art to become alive ${ }^{3}$.

In the context of this blurring, many contemporary artists have heavily explored what Nicolas Bourriaud called relational aesthetics $^{26}$ : an intensive casual encounter regime that places art on the horizon of human exchanges and of human social context, accentuating art's prerogative of generating unusual relationships with the world. Relational aesthetics produces collective artistic configurations with a foundation that is given by intersubjectivity and having as a central point this 'being-together' and allowing the creation of connection networks, highlighting sometimes modest or everyday situations, landscapes and even what has been obstructed, silenced or separated. Starting from the motto of cohabitation, these proposals call into question the rigid and standardized forms of human relationships, giving way to new ways of relating, of loving, of living. They are places where alternative forms of sociability are elaborated and moments of coexistence are built, producing relational space-times trying to free themselves from the restrictions of mass communication.

This way, contemporary art contributes for singularities to coexist in a common world, showing a precious tuning with anti-asylum 
proposals. From the material that weaves life together - the prosaic, the everyday and the unexpected - visual arts provide means of expression in exercises of collective collaboration, establishing a state of participation with the world. As stated by Bourriaud 26(51) "it is not more than that, but it is a lot". Starting from small gestures, using few resources, often precarious, art turns to the task of "patiently resewing the fabric of relationships".

In the visual arts workshop, relying on what we had - above all, with ourselves, our bodies and lives -, a series of meetings were held where objects and events were produced in the languages of collage, assembly or performance, trying to provide a form to the content that emerged in the group. With relational aesthetics as a reference, we thought of the workshop itself as a work of art, insofar as it operated within the horizon of coexistence and social interactions. Films, documentaries, conversation circles, debates, artistic references served as a springboard for the production of objects or artistic performances that mainly problematized themes such as gender and sexuality, which would emerge from the meetings, which led to the creation of the 'Collective Diverse Many' .

By offering the workshop as a territory of existence, a field of aesthetic experience and social connection, the proposal brings together artistic and clinical practices, encompassing what is expected from psychosocial care policies, stressing once again that artistic activity is a privileged field for the construction of new subjectivities, of new ways of being together that can be powerful, generous and more solidary.

\section{A Belly Dance Workshop: making womanhood dance}

At the Rosa dos Ventos Coexistence Center, in Campinas, the team develops practices connected to new forms of production and of sensitivities in the field of care. Among them, craft workshops, yoga practices, arts studio and a belly dance group. The Community Centers emerged during the $\mathrm{RPb}$ process and develop actions that focus on the production of meetings between mental health users and the community in which they live, through workshops, and community groups and actions. It is an equipment idealized according to SUS guidelines and psychosocial care, where coexistence, belonging and group awareness are promoted in the relationship with the territory, with the health network, with the community, seeking to build intersectoral relationships and making interfaces with cultural and artistic actions ${ }^{2}$.

The dance group was founded in 2011 and currently has around 30 participants. From the beginning, many women of different ages gathered there, arriving from very different places and paths. Grandmothers would come with their granddaughters and daughters, looking for the group spontaneously; adolescents would arrive on the recommendation of other girls; women would be referred to the group by teams from Health Centers, Psychosocial Care Centers, the Eating Disorders Outpatient Clinic, and the Reference Center for Women Victims of Violence. And, so, they have been arriving and recommending the dance space for other women.

The work developed comprises traditional movements of Arab oriental dance with stretching, improvisation movements, awareness practices and body expression aligned with the approaches of the Klauss Vianna Technique, creating spaces for the group to build a unique body language based on listening to the body and on movement research and investigation.

Over these years, we shared scenicartistic works, aesthetic experiences, transited through events in the health circuit and entered the universe of dance, art and culture in Campinas. These are experiences that expand the repertoire of women's experiences, strengthening the group awareness and building other places and other ways of being able to live life, enhancing it, intensifying it. 
The focus of the work is not exclusively therapeutic, artistic, pedagogical or social. The device is tested in its hybrid character, so that the universe of arts, care and health promotion is made transversal, blurring borders and creating spaces of intercession in the production of encounters.

To dance in performances and events, it is necessary to prepare the bodies and build the characters. The women dress together, attentive to makeup, hair, costumes, accessories. Bypassing the crystallized places of everyday life, they transport themselves to other universes, connect to other forms of expression and language and access the feminine realm, so invaded and devastated today. There is not one only Maria: there is a Maria-womanworker-dancer; a Maria-woman-mother who also dances; a Maria-woman marked by loss and suffering; there are many Marias who are labelled by their marks and who move to another place when they dance, inaugurating new existential territories.

It is not a matter of making culture therapeutical in times when life is made pathological. It is about enabling the experimentation of intensive forms of life. Putting the body in other movements, experimenting with expressive languages, in new directions, to trigger subjectivation processes.

Talking about the dance group at the Centro de Convivência Rosa dos Ventos makes us share testimonies of lives that have expanded and moved away from the normative sense based on ideal health. It is necessary to think and exercise a different understanding of health that may bring us closer to the expressive processes as a means to potentialize life. A fragile health ${ }^{27}$, which, precisely because of its fragility, gains intensity along the lines of life, clinging to potencies.

\section{A Theater Workshop: experiences in crossing}

The bodies are in a crossing. The states are constantly changing, as they are in an experimentation plan, departing from a known territory to embark on a journey to affection:

$[\ldots .$.$] it is not a matter of favoring the body over$ the spirit: it is rather a question of acquiring knowledge of the potencies of the body in order to discover at the same time the potencies of the spirit that escape consciousness ${ }^{28(77)}$.

When they meet, bodies both affect and are affected, both attract and repel each other. The vibrating, imperceptible body is activated, and the organism body reaches another state of attention. And so, in the composition of this meeting, a consistency plan is drawn, outlining a territory. Geography is existential. The sensations mark the body, forging an affective memory, weaving cartographies and making narratives emerge, such as the one below.

Winter. A blue skies Friday afternoon. The green of the fig tree beyond the wall. In our backyard there ought to be shade and also sunshine. The workshop starts and we are all a little discouraged. The fabric, outlining the arena, cds, books, balls, they are all there. Nice arrived, already sat on the floor and seems more restless today. Silvia walks around watching. Seo Chico, already lying with his feet in the sun, watches time pass by. A silence of millennia suspends us. I had prepared a class script but, immersed in this atmosphere, I realized that the bodies were asking for a ground and that it was already warm enough up to welcome us. An extended width. Being able to lie down together... horizontalize... stretch and, in contact with the ground, breathe, letting the air come in and out, stretching and elongating (the limit is the body itself) hands, feet, arms, legs... and soon then relax by surrendering to the ground. Letting out sounds if the body asks for a voice. Discomfort, complaints? Silvia stops and turns to the side, I approach her and her eyes are closed like a child who has snuggled. Nice breathes, lets out her voice, making a soliloquy, describing the bodily sensations. Meanwhile, Seo Chico transcends, immersed in the temperature of 
the ground, in his way of seeing things as a child - seed silence? I introduce music that starts to give rhythm to the moment and people start making body movements, always at the pace of each one's desire. With my voice I invite them to experiment ways of walking (feet and hands, crawling, tiptoeing, heels, inner and outer feet) at different speeds that gradually accelerate and decelerate. Bodies that, when meeting other bodies, have a dialogue with movement, with perspective, in silence of speech. Keep moving until you return to the starting position. Seo Chico gets up and sits down, legs crossed, watching what happens. Silvia tries the ways of walking and has fun, little by little she seems to stop. Nice finds it difficult to walk, but she figures it out herself, not without complaining experimenting with different intensities: walking like a bird, like a tiger, like a spider; galloping, leaping like a kangaroo and digging her feet into the ground as if it was made of mud. She is focused on her doing and intensifies her movements along with her vocal expression in a continuously aligned with her body's expression. Nice grows and affects the entire group to produce collectively. The participants start a body-vocal dialogue that remains for time there is a desire for interaction. To finish the workshop, we shared in a circle how the experience was for each one of us. We're sweating, asking if it's over, if now there is a snack, getting up, putting on our shoes... Nice is sitting and, still resonating with the experience, looks up and touches her outstretched legs. There is a tremor: 'Wow! I felt today that I have a leg. Look how my legs are? And it is not because of Haldol, it is different'. Silence. We looked each other. 'I'm the one who knows about my body!'. She laughs. We all laugh ${ }^{6(75,76)}$.

The possibility of experiencing her body in a way other than usual drew a consistency plan in which Nice's capacity to become something else went through different stages. Swimming, floating, drowning, paddling together. By producing something unique, this something goes beyond her. (Re)inventions of oneself and the world.
The work in an unfinished process, taking place in a Caps in the interior of São Paulo.

\section{A Literature Workshop: a life made fiction}

Among the types of workshops found in the experiences of psychosocial care, there are the literature workshops, in which forms of expression through the word are worked on. Experiences with literature offer possibilities to talk about pain and, in this sense, forge tools that will in dealing with suffering. Communicating this experience allows to make brands and to have them registered in the world. The accounts and narratives potentiate the desire to risk existing far beyond the diagnosis, which, by becoming a label, restricts self-recognition and self-worth.

Stories have the power to teach, preserve memory or alter the past; in them, lives are like texts subject to revision, where the author is also the interpreter of himself, which enables an approximation to fiction in the sense of permanent re-elaboration, of self-invention ${ }^{29(1308)}$.

A literature workshop experience took place in 2012, in a city in the interior of Paraná. The proposal sought to provide a space for listening and welcoming users of the city's health service, in particular, mental health users. At first, in order to clarify the proposal, some conversation circles were organized. It was observed that users had great difficulty in understanding how this work could contribute to the treatment, since the care provided by this service was almost exclusively outpatient care, with monthly consultations and medication prescription, which users and family members considered the only and best form of health care.

To facilitate the arrival of interested parties to the workshop, and to face both the condition of 'psychiatrization' that compromises the integrality of care and the difficulties in getting to the service, it was decided to make access more flexible: the workshops took place on 
different days, in the Basic Health Unit, which operated in the same building as the Mental Health Clinic, during the service's opening hours. The day for the user's participation could be the same of his consultation.

At the meetings, books with poetry, some texts and materials were made available for participants to produce their own writings if they so wished. From this triggering proposal, personal and family issues, exchange of experiences, problematization of everyday situations and expectations regarding the treatment emerged in the form of narratives. The texts in germination allowed to glimpse sketches of life daring to exist.

In this experience, we tried to think of literature workshops as a tool for clinical care in mental health. In a context where care still ran into a medicalization and individualist model, based on the disease, art and literature productions emerged as a way to transgress this utilitarian logic.

To think about literature and its relationship with insanity is to think about resisting discourses that reduce subjectivity to identity; it is to think about singularization processes. Literature is the art of creating or recreating texts through writing and speech, in order to transgress the control of bodies and subjectivity, allowing for a certain plasticity in relation to the world inhabited by insanity ${ }^{4}$. It is through narrative (due to its approach to fiction) that a reinvention movement is possible, and the group, in turn, is the space where this resistance is materialized in a permanent re-elaboration of experiences.

According to Foucault ${ }^{30}$, resistance is not a process of crystallization, but of combat and, above all, of creating new ways of being and feeling, of transforming situations and of transforming oneself. Jumping from the symptomatology plan to that of experiencing was the exercise practiced in the workshop meetings. An event that marks the thought-bodies of those who crossed and let themselves be crossed by the intensive force of life.

\section{Making music and movement}

Music, in the context of $\mathrm{RPb}$, points to a diversity of practices with different formats, objectives and methods. In a survey conducted in this field, five main ways of working with music were identified, and organized into the following categories: music therapy; sound and/or music workshops; bands, choirs, group and solo music; carnival troupes; and radio and web-radio experiences ${ }^{5}$.

Among these different formats, the attention is drawn to the musical groups that circulate in the popular music scene. In frontier territories, by inhabiting intersectoral proposals, these groups that explore multiple musical styles and genres venture into an existence without fixed institutional ties. Many of these groups had their origin in health service contexts and became detached from them, seeking autonomy and an insertion in the artistic-cultural circuits. Thus, they continue to sustain themselves, sometimes precariously, through partnership and cooperation that allow them a physical venue to promote their rehearsals, connections with other players in health and culture and participation in the training of students and researchers who wish to connect to these experiences, among other possibilities that feed a persistence in this hybrid territory. Examples of experiences like these can be found in the trajectories of the Projeto Cidadãos Cantantes and of Banda Lokonaboa, which we will present below.

\section{THE SINGING CITIZENS PROJECT}

In 1992, the Mental Health Scenic Choir came to be, in the form of an open workshop, at the São Paulo Cultural Center (CCSP), combining artistic production with the production of health and subjectivity. Ten years later, linked to this project, the Dance and Body Expression Workshop was born, when the choir was renamed Projeto Cidadãos Cantantes (Singing Citizens Project), comprising choir and dance workshops and promoting spaces of singularity and collective invention ${ }^{8}$. 
The Oficina de Coral Cênico (Scenic Choir Workshop) works with different rhythms, speeds, ideas and tastes. In it, each voice matters, and each one takes some care of the other one. The relationships established in the rehearsal room overflow it, producing friendships and taking the singing to other spaces, to meet the public. The work of conducting, which has been described as that of "fine tuning the differences"31(124), seeks an unusual harmony in the set of so many different voices in their timbres and tunings. When the group explores a collective tuning, it is not looking for perfection, which could hinder the creative process, imposing a sieve to the selection of songs due to the participants' ability to maintain high and low sounds. The tuning is built as an attempt to compose voices, hear and perceive the voice color of each one, in a collective challenge to produce a connection with the meanings of what is being worked on in the repertoires. The encouragement of compositions by the participants themselves is strong, and poetry and lyrics that appear there are commonly used in the repertoires, in a creation made by many. The lyrics of the songs weave the work with their expressive force. They are important elements in the Choir's work; when choosing them, connections are made between sounds and utterances, emerging a theme that constitutes the axis of the work at a given moment. The choir's performances are events that already start when things are one their way, when the vocal warm-up is still taking place: the group is talking, remembering the lyrics, singing songs from old repertoires. Before entering the scene, everyone prepares together, sharing makeup and props. Minor mismatches pop up at the time of the presentation, but the response from the audience is always very strong and welcoming.

The Dance and Body Expression Workshop (Odec) is a laboratory for movement and improvisation contact: bodies meet with each other and with themselves, with the shapes they have, with their possibilities of inhabiting spaces, with the sensations that emerge from experimentation. From the investigation of the movements, a quality of connection with oneself is possible, which enhances the encounter with the other one and helps to build relationships. Hence the power of dance to promote the exercise of self-appropriation and the possibilities of transforming and linking is explored. Each meeting is different, has its own atmosphere, a particular sequence of songs, a configuration given by the people present, a proposal built on that day. These collective poetic constructions make allow to enter into game states with what is placed in the social field, so that a singular expression can emerge.

Poiéses are acts of weaving meanings and forming poetics with different materials, with elements of a collective field, with sounds and with the body. These deviant collective productions are also acts of resistance, since, through them, there is an expercience of bodies, languages and sensitivity that build escapes from the normative and capitalist use of the body and the 'shaping forms', with which we are daily bombarded in the media and on social networks, which convey body care as surveillance.

\section{THE LOKONABOA BAND}

Another musical experience that was followed up in our research was that of Banda Lokonaboa, an initiative of the 'Psychosocial Care in Collective Health' University Extension Project of the Psychology Course at UnespAssis. In its embryonic form, the band was a music workshop offered by Caps Ruy de Souza Dias, from the city of Assis, and its students linked to the extension project. The workshop was developed for several years, and the group performed at events of Luta Antimanicomial (Anti-asylum Movement) or of the college, until, in 2002, the idea of creating a band came up, which was a natural offshoot of the project, given its musical quality.

Later, the band established a partnership with Pirassis, the Association of workers, 
family, friends and mental health users in the city. In 2009, the rehearsals began to take place at Galpão Cultural de Assis, a space shared by various groups and Non-Government Organizations (NGOs), which had become a Culture Point.

Based on a decentralized and non-hierarchical management proposal, the band used a democratic perspective when making decisions about costumes, repertoire, use of resources and aesthetic proposal. It sought, therefore, to introduce transformations that also affected micropowers, seeking the horizontalization of power relations.

The project has always worked with a perspective that is directly articulated with the sociocultural dimension of the Psychiatric Reform: the production of a social space for insanity. To be able to engage in a dialogue between the so called healthy and the unhealthy,

before, it is necessary to demistify, displace, our experience of insanity, in order to allow the word of the 'insane' to be accepted. For it to be no longer an interdicted word7(90).

This issue can be grasped when one considers that the band's performances cause a feeling of strangeness and rupture in the listeners' perspective, building moments of cultural recognition of the manifestations of the insane.

But the Band's experience causes alterations in the sound and sensitive landscapes, mainly of its members. The creation of brands, the appropriation of content, the reorganization of sensations, which gain meanings, all of this enables the construction of subjective territories, inserted in their own temporality and rhythmicity, which find a place in the world ${ }^{32}$.

\section{A few thoughts to conclude}

In the exercises and experiences that we could glimpse in the brief reports above, arts, culture and clinic cross each other, enhancing their vectors of invention and connecting the processes of creation to the production of health and subjectivity. Sketching exercises like these, which touch on political action and the invention of new ways of life and living, is urgent for everyone of $\mathrm{us}^{33}$.

These are actions that promote new articulations between unique experiences and collective life, making it possible to go beyond the notion of art and culture as therapeutic resources and be able to access their clinical potential, as an aesthetic experience bringing new meanings to life. In the construction of proposals that restore life in the collective and creative dimension, possibilities of belonging are expanded, forms of encounter and coexistence are strengthened and cultural participation is intensified, which contributes to the implementation of truly public policies.

The proposition of public policies and intersectoral actions highlights the public and common character of arts, health and culture. It is about progressively providing sedimentation to transversality between processes of subjectivation and processes of constitution of the world, which have as reference the production of what is common. The issue at hand here are public and collective experiments in the world that is common, which include the invention of existential territories, the creation of values and the constitution of subjectivation processes, having as a criterion the expansion of life, and not its exploration, limitation or restriction. "The dimension of what is Common is not a choice, but an imperative of human life, in its radical requirement of relationship, of alterity"23(121).

In the current political moment, in which government and state policies abandon the collective and public plans, recent experiments in the fields of mental health, arts and culture that sought and somehow seek to open up towards the public dimension that all political actions should encompass are an invaluable immaterial heritage for fairer and more democratic future re-compositions of the policy to come. 


\section{Acknowledgements}

We would like to thank the Graduate Program in Psychology at Paulista State University (Unesp), Assis Campus, the Coordination for the Improvement of Higher Education Personnel (Capes) and the Foundation for Research Support of the State of São Paulo (Fapesp) for all the support we received throughout the years we developed our research. We would also like to thank Professor Silvio Yasui for the partnership and support he offered us during the development of our research project.

\section{Collaborators}

Lima EA (0000-0003-0590-620X)* coordinated the preparation of this collective article, organizing the process, participating in the writing along with the other authors and making the final text proofreading. Providello G (00000001-9069-6571)*, Silva JA (0000-0002-20289417)*, Aleixo JMP (0000-0002-7120-7725)*, Pellegrini L (0000-0002-9867-0621)*, Aversa PC (0000-0002-9348-1266)*, Barrenha T (00000001-6828-4482)* and Cardoso TM (0000-00034293-4963)* contributed to the making of the manuscript, having participated in its conception, text writing and approval of final version.

\section{References}

1. Arendt H. A condição humana. Rio de Janeiro: Forense Universitária; 2003.

2. Aleixo JMP. Centro de Conviv ência e Atenção Psicossocial: Invenção e produção de encontros no território da diversidade. [dissertação]. Assis: Universidade Estadual Paulista; 2016. 117 p.

3. Aversa PC. Passagens: encontros em artes, produções de vida. [tese]. Assis: Universidade Estadual Paulista; $2018.170 \mathrm{p}$.

*Orcid (Open Researcher and Contributor ID).
4. Barrenha TS. Escrever para não morrer: Stela do Patrocínio e a literatura como dispositivo de resistên- cia, cuidado e produção de subjetividade. [dissertação]. Universidade Estadual Paulista; 2019. 86 p.

5. Cardoso TM. A que(m) serve a Música na Reforma Psiquiátrica brasileira? Linhas de Audibilidade nas práticas musicais e sonoras da Saúde Mental Coletiva. [dissertação]. Universidade Estadual Paulista; 2014. 184 p.

6. Ferreira LVP. Corpos em travessia: ensaio de uma clínica dos fluxos. [dissertação]. Universidade Estadual Paulista; 2016. 109 p.

7. Providello GGD. Projeto Banda Lokonaboa: criando um 
acorde entre arte, loucura e Reforma Psiquiátrica. [dissertação]. Universidade Estadual Paulista; 2011. 104 p.

8. Silva JA. Poéticas e marginalidades: experiência no Projeto Cidadãos Cantantes. [dissertação]. Universidade Estadual Paulista; 2012. 212 p.

9. Cardoso TM. Tem barulho nesse emaranhado: ensaios sobre música, poder e subjetividade e proposição das linhas de audibilidade para análise de dispositivos sonoro-musicais. [tese]. Assis: Universidade Estadual Paulista; 2020. 185 p.

10. Passos E, Barros RB. A construção do plano da clínica e o conceito de transdisciplinaridade. Psic.: Teor. e Pesq. 2000; 16(1):71-79.

11. Barros RB, Passos E. A humanização como dimensão pública das políticas de saúde. Ciênc. Saúde Colet. 2005 ; 10(3):561-571.

12. Rotelli F. Desinstitucionalização. São Paulo: Hucitec; 2001.

13. Amarante P. Saúde mental e atenção psicossocial. 4. ed. Rio de Janeiro: Fiocruz; 2013.

14. Costa-Rosa A, Luzio CA, Yasui S. Atenção Psicossocial: rumo a um novo paradigma na Saúde Mental Coletiva. In: Amarante PA, organizador. Archivos de Saúde Mental e Atenção Psicossocial. Rio de Janeiro: NAU; 2003. p. 13-44.

15. Costa-Rosa A. Atenção Psicossocial além da Reforma Psiquiátrica. São Paulo: Editora UNESP; 2013.

16. Costa-Rosa A, Yasui S. A Estratégia Atenção Psicossocial: desafio na prática dos novos dispositivos de Saúde Mental. Saúde debate. 2008; $32(78 / 79 / 80): 27-37$

17. Lima EMFA. A Saúde Mental nos caminhos da Terapia Ocupacional. Mundo saúde. 2006; 30(1):117-122.

18. Lima L, Ortellado P. Da compra de produtos e serviços culturais ao direito de produzir cultura. Dados. 2013; 56(2):351-382.
19. United Nations Educational, Scientific and Cultural Organization. The General Conference of the United Nations Educational, Scientific and Cultural Organization. The 2005 Convention on the Protection and Promotion of the Diversity of Cultural Expressions. Paris, 2005. [acesso em 2020 jan 30]. Disponível em: https://en.unesco.org/creativity/sites/creativity/files/passeport-convention2005-web2.pdf.

20. Brasil. Ministério da Cultura. Loucos pela Diversidade: da diversidade da loucura à identidade da cultura. Relatório Final. Oficina Nacional de Indicação de Políticas Públicas Culturais para pessoas em sofrimento mental e em situações de risco social. Rio de Janeiro: LAPS; 2008.

21. Amarante P, Torres EHG. Loucura e Diversidade Cultural: inovação e ruptura nas experiências de Arte e Cultura da Reforma Psiquiátrica e do campo da Saúde Mental no Brasil. Interface. 2017; 21(63):763-774.

22. Yasui S. Rupturas e encontros: desafios da Reforma Psiquiátrica Brasileira. Rio de Janeiro: Fiocruz; 2010.

23. Guizard F, Cavalcanti F. Por um mundo democrático produzido democraticamente. Lugar Comum. 2009; 27(1):103-123.

24. Lancetti A. Clínica Peripatética. São Paulo: Hucitec; 2008.

25. Lima EMFA, Yasui S. Territórios e Sentidos: espaço, cultura, subjetividade e cuidado na Atenção Psicossocial. Saúde debate. 2014; 38(107): 593-606.

26. Bourriaud N. Estética Relacional. São Paulo: Martins Fontes; 2009.

27. Deleuze G. Conversações. São Paulo: Editora 34; 2010.

28. Deleuze G. Filosofia Prática. São Paulo: Escuta, 2002.

29. Meneguel SN, Moraes SCC. Oficinas de pontos e narrativas: produções discursivas de cuidado em um Centro de Atenção Psicossocial (CAPS). Rev. Mal-Estar Subj. 2009; 9(4):1303-1322. 
30. Foucault M. A ética do cuidado de si como prática da liberdade. In: Foucault M. Ética, sexualidade, política. Ditos e Escritos V. Rio de Janeiro: Forense Universitária; 2004.

31. Maluf JCG. Afinando diferenças: o processo de construção artística do Coral Cênico Cidadãos Cantantes. [dissertação]. São Paulo: Universidade Estadual Paulista; $2005.331 \mathrm{p}$.

32. Providello GGD. Música e subjetividade: experimentações híbridas do pensamento. [tese]. Assis: Universidade Estadual Paulista Júlio de Mesquita Filho; 2018. $100 \mathrm{p}$
33. Lima EMFA. Explorando arte e corpo em um campo expandido: Uma experiência de produção de comum. Ilinx Revista Lume. 2017; 12(3):8-90.

Received on 03/03/2020

Approved on 08/18/2020

Conflict of interests: non-existent

Financial support: Coordination for the Improvement of Higher Education Personnel (Capes) - Financing Codes 001 (one Master's and one Doctor's scholarships in the Country, one of them with the benefit of doctoral 'sandwich' training); Coordination for the Improvement of Higher Education Personnel (Capes) - Process no 1750406 (Doctor's Scholarship in the country); Foundation for Research Support of the State of São Paulo Coordination for the Improvement of Higher Education Personnel (Fapesp) - process 2011/16633-7 (Master's Program Scholarship) 